\title{
Evaluation of buccal swabs for pharmacogenetics
}

\author{
J. Sidney Ang ${ }^{1}$, Martin N. Aloise ${ }^{1}$, Diana Dawes ${ }^{1,2}$, Maryn G. Dempster ${ }^{1,3}$, Robert Fraser ${ }^{4,5}$, Andrea Paterson ${ }^{1,6}$, \\ Paul Stanley ${ }^{1}$, Adriana Suarez-Gonzalez ${ }^{1}$, Martin Dawes ${ }^{1,7}$ and Hagit Katzov-Eckert ${ }^{1 *}$ (])
}

\begin{abstract}
Objective: A simple, non-invasive sample collection method is key for the integration of pharmacogenetics into clinical practice. The aim of this study was to gain samples for pharmacogenetic testing and evaluate the variation between dry-flocked and sponge-tipped buccal swabs in yield and quality of DNA isolated.

Results: Thirty-one participants collected samples using dry-flocked swabs and sponge-tipped swabs. Samples were assessed for DNA yield, quality and genotyping performance on a qPCR OpenArray platform of 28 pharmacogenetic SNPs and a CYP2D6 TaqMan copy number variant. DNA from sponge-tipped swabs had a significantly greater yield compared to DNA collected with dry-flocked swabs $\left(p=4.4 \times 10^{-7}\right)$. Moreover, highest genotyping call rates across all assays and highest CNV confidence scores were observed in DNA samples collected from sponge-tipped swabs ( $97 \%$ vs. $54 \%$ dry-flocked swabs; 0.99 vs. 0.88 dry-flocked swabs, respectively). Sample collection using sponge-tipped swabs provides a DNA source of sufficient quantity and quality for pharmacogenetic variant detection using qPCR.
\end{abstract}

Keywords: Sample collection, Buccal swabs, OpenArray, Copy number variation, Pharmacogenetics

\section{Introduction}

Pharmacogenetics is a rapidly advancing field that has the potential to improve the safety and efficacy of medications by individually tailoring dosage and drug choices based on genetic profiles [1-3]. There is increasing evidence for the clinical utility of pharmacogenetics [2, 4]; guidelines from the Clinical Pharmacogenetics Implementation Consortium (CPIC) and the Dutch Pharmacogenetics Working Group (DPWG) that outline drug-gene interactions, are facilitating the clinical use of pharmacogenetic test results [5-7]. For clinicians to integrate pharmacogenetics into their care and use this knowledge, there needs to be an easy, cheap method of collecting samples that results in DNA of good quality.

Clinical diagnostics and genetic studies have traditionally used blood samples. Obtaining blood is invasive, costly, and may not be necessary for pharmacogenetics, where easy to collect, less costly alternatives such

\footnotetext{
${ }^{*}$ Correspondence: hagit.ke@genxys.com

${ }^{1}$ GenXys Health Care Systems Inc., Vancouver, BC, Canada

Full list of author information is available at the end of the article
}

as saliva and buccal swabs can be used. In a published study, we used the Oragene saliva collection kit (DNA Genotek, Ottawa, ON); saliva samples resulted in a high mean DNA yield $(6.0 \pm 3.9 \mu \mathrm{g})$ [4]. Other studies have also shown high DNA yield from the Oragene saliva collection kit [8-10]. Although saliva sampling for genetic testing has gained acceptance [11-13], some patients in our study found it difficult to spit into a tube while others found it difficult to produce enough saliva $(2 \mathrm{ml}$ per sample). Dry mouth is a common side effect of medications and can hinder saliva collection. Hence, we sought to evaluate alternative sample collection methods for pharmacogenetic testing.

Evidence varies on the use of buccal cell DNA for genotyping [14], with a tendency for buccal swabs to yield less DNA compared to saliva collection [15-17]. More recent studies have evaluated the usefulness of swabs for genetic applications (see Additional file 1). To provide an easy way for patients to collect samples at the clinic, pharmacy or in the comfort of their own homes, we evaluated the performance of two swab types available on the market: a dry-flocked swab (Puritan PurFlock) and a sponge-tipped

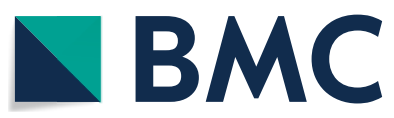

(c) The Author(s) 2018. This article is distributed under the terms of the Creative Commons Attribution 4.0 International License (http://creativecommons.org/licenses/by/4.0/), which permits unrestricted use, distribution, and reproduction in any medium, provided you give appropriate credit to the original author(s) and the source, provide a link to the Creative Commons license, and indicate if changes were made. The Creative Commons Public Domain Dedication waiver (http://creativecommons.org/ publicdomain/zero/1.0/) applies to the data made available in this article, unless otherwise stated. 
swab with a stabilizing solution (Oragene ORAcollect). We compared the DNA yield and genotyping quality from the swabs on a pharmacogenetic panel of 28 single nucleotide polymorphisms (SNP) and a cytochrome P450 family 2 subfamily D member 6 (CYP2D6) copy number variation $(\mathrm{CNV})$ assay.

\section{Main text}

Materials and methods

\section{Sample collection}

Participants aged 18 years and over were invited to join the study via email notifications and advertisements placed on bulletin boards at the University of British Columbia, Vancouver BC. Participants were asked to provide samples using dry-flocked buccal swabs (Puritan PurFlock, Fisher Scientific, Waltham MA) and spongetipped buccal swab (Oragene ORAcollect, DNA Genotek, Ottawa, ON) using self-guided instructions; the order in which these samples were given was computer randomized. A research assistant was present during sample collection to answer questions participants had regarding the instructions for sample collection. All samples were stored at room temperature. Pharmacogenetic reports were not given to participants, as this was not within the scope of this study.

\section{DNA extraction}

DNA was extracted using the Ambion MagMAX beadbased DNA extraction kit (Applied Biosystems, Foster City, CA) according to the manufacturer's instructions. DNA was extracted 3 days after sample collection and eluted in $60 \mu \mathrm{l}$. DNA quantity and quality were assessed using Qubit 2.0 fluorescence assay (ThermoFisher Scientific, Waltham MA). The purity of samples was determined by the optical density A260/280 ( $\left.\mathrm{OD}_{\mathrm{A} 260 / 280}\right)$ values using NanoVue spectrophotometer.

\section{Genotyping}

Genotyping was performed on the QuantStudio 12K Flex quantitative polymerase chain reaction (qPCR) instrument (LifeTechnologies, Carlsbad, CA) on assays validated by the manufacturer (ThermoFisher Scientific, Waltham MA). The content of the assays included 28 SNPs influencing drug response on the OpenArray platform (see Additional file 2) and a CYP2D6 CNV TaqMan assay (Assay ID: Hs_00010001_cn). To validate assays, 44 DNA controls from the National Institute of General Medical Sciences (NIGMS), Human Genetic Cell Repository at the Coriell Institute for Medical Research were genotyped. Concordance of calls was confirmed with the expected genotype. In addition Sanger sequencing of the control DNA verified results. For each run, participant samples were run in duplicates on the OpenArray and quadruplicates on the CNV assay along with Corriell DNA samples used as positive controls and no template controls (NTCs).

\section{Statistical analysis}

The TaqMan Genotyper software v1.3.1 (Applied Biosystems) was used to determine SNP genotyping call rates on the OpenArray. Genotype call rate was calculated for each OpenArray assay, dividing the total number of successfully assigned genotypes by the total number of attempted genotype assignments.

For the CNV TaqMan assay CopyCaller v2.1 software (Applied Biosystems, Foster City, CA) was used to assign CYP2D6 copy number calls and CNV confidence scores. DNA samples were assigned a wild type diploid copy number and copy number variation (deletion or duplication events) were grouped in the $2 \mathrm{~N}$ and $\mathrm{CNV}$ groups, respectively. A 95\% genotyping call rate and $95 \%$ confidence score was set for SNP and CNV genotyping results, respectively. A two-sample Student's t-test assuming unequal variances was calculated to determine the significant difference between DNA yield, purity and call rates from the different DNA types in pairs. The genotyping assignments generated from the DNA sample type (sponge-tipped vs dry-flocked) from the same participant were compared to calculate concordance.

\section{Results}

Thirty-one participants were recruited and collected sponge-tipped swabs and dry-flocked swabs. Participants found self-guided instructions for collection straightforward and easy to follow for both types of swab. Participants raised questions on the necessary pressure for rubbing the swabs and the correct placement of swabs in the mouth. Comments from participants about the two swabs were similar with some preferring sponge-tipped swabs and others preferring the dry-flocked swabs; there was no consensus of opinion.

There was a significant difference in mean DNA yield between DNA collected using dry-flocked swabs versus sponge-tipped swabs $(0.26 \pm 0.34 \mu \mathrm{g}$ vs. $1.91 \pm 1.44 \mu \mathrm{g}$ $\mathrm{p}=4.4 \times 10^{-7}$; Table 1 ). Mean DNA purity across all collection types were in the accepted range of for pure DNA (mean (SD)) 1.72(0.78) and 1.85(0.39) for dry swabs and sponge-tipped swabs, respectively.

There were three samples collected from sponge-tipped swabs that had low DNA concentrations $(<5 \mathrm{ng} / \mu \mathrm{l})$. These three samples had $100 \%$ genotyping call rates on the OpenArray and 100\% CNV confidence scores (Fig. 1). Conversely, one of the samples that had DNA concentration of $79 \mathrm{ng} / \mu \mathrm{l}$ had the lowest OpenArray call rate (18\%). The highest call rates on the OpenArray ( $>95 \%)$ for dryflocked swabs were observed for seven samples with 
Table 1 Quantity and purity of DNA from sponge-tipped and dry-flocked swabs

\begin{tabular}{|c|c|c|c|c|c|c|c|c|}
\hline \multirow[t]{2}{*}{ Swab type } & \multicolumn{4}{|c|}{ Yield $(\mu \mathrm{g})$} & \multicolumn{4}{|c|}{ Purity $\left(O D_{A 260 / A 280}\right)$} \\
\hline & Mean & SD & Min & Max & Mean & SD & Min & Max \\
\hline Sponge-tipped swabs $(n=31)$ & 1.91 & 1.44 & 0.26 & 5.57 & 1.85 & 0.39 & 0.65 & 2.43 \\
\hline Dry-flocked swabs $(n=31)$ & 0.26 & 0.34 & 0.06 & 1.46 & 1.72 & 0.78 & 0.14 & 3.10 \\
\hline Significance & \multicolumn{4}{|c|}{ p-value $=4.4^{-7}$} & \multicolumn{4}{|c|}{$p$-value $=0.4$} \\
\hline
\end{tabular}

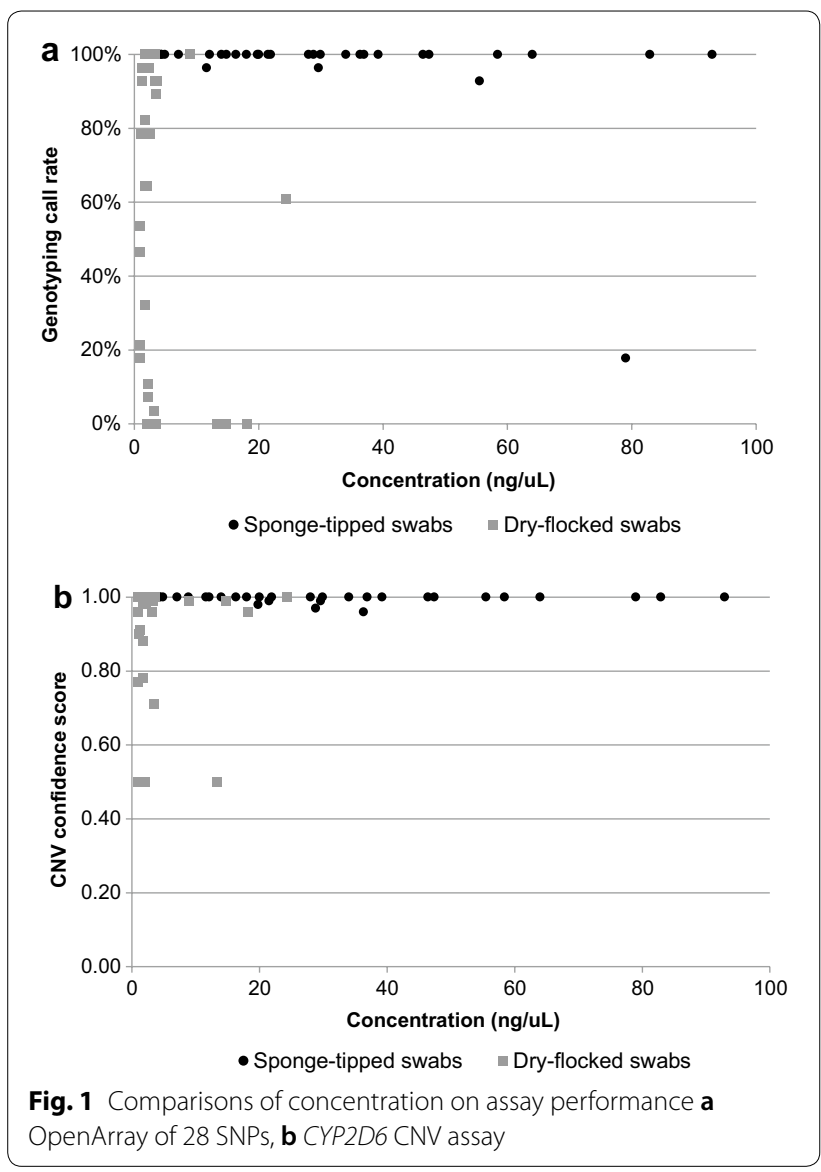

concentration ranging between 1.2 and $8.9 \mathrm{ng} / \mu \mathrm{l}$ (Fig. 1a). The highest CNV confidence calls (>95\%) were observed for samples with concentration ranging between 1.0 and $24.4 \mathrm{ng} / \mu \mathrm{l}$ (Fig. 1b).

For all the assays on the OpenArray, DNA samples collected from sponge-tipped swabs resulted in overall higher genotyping call rates (97\%) compared to dryflocked swabs (54\%) (Fig. 2). With an added step of a $0.5 \times$ dilution of extracted DNA, the sponge-tipped swabs had consistent genotyping call rate $>95 \%$. Sample call rate on the OpenArray varied by individual with 29(93.5\%) participants having sample call rates $>95 \%$ from sponge-tipped swab DNA and 4(12.9\%) having sample call rates $>95 \%$ from dry-flocked swab DNA. A
94\% concordance of successfully genotyped assays was observed between sponge-tipped swabs and dry-flocked swabs collected from the same individual.

Copy number calls for CYP2D6 were assigned to $2(6.5 \%)$ of the samples from sponge-tipped swabs with an overall confidence score of 0.99 . In comparison, $8(25.8 \%)$ of the samples from dry-flocked swabs were assigned copy number calls with an overall confidence score of 0.91 (see Additional file 3).

\section{Discussion}

The purpose for this research is to help investigators, and companies, identify an optimal collection method that yields high-quality DNA for genotyping. This study provides new information on the DNA quality for two types of swabs, which was high (defined as $\mathrm{OD}_{\mathrm{A} 260 / \mathrm{A} 280} 1.8$ ) $[18,19]$ though there was a significant difference in DNA yield $\left(\mathrm{p}\right.$-value $\left.=4.4^{-7}\right)$. On the OpenArray platform, sponge-tipped swabs had the highest overall genotyping call rate (97\% vs. $54 \%)$ and highest confidence score for CYP2D6 CNV TaqMan Assay (0.99 vs. 0.91). A > 95\% SNP genotyping call rate is considered to reflect acceptable quality data and CNV confidence score of $99 \%$ is considered high quality [20-22].

One DNA sample isolated from the sponge-tipped swab had a call rate below $95 \%$. In routine lab practice, samples with low call rates would be recollected due to incomplete results for patient reports. Omitting this sample increased the overall genotyping call rate to $99.5 \%$ for the sponge-tipped swabs.

CYP2D6 CNV results showed an increase of CNV assignments for DNA collected from dry-flocked swabs $8(25.8 \%)$ compared to sponge-tipped swabs $2(6.5 \%)$. Higher number of $\mathrm{CNV}$ assignments correlated with lower confidence scores. The majority of participants $30(97 \%)$ were able to collect samples that resulted in high genotyping call rates for the sponge-tipped swab while only a few individuals $4(13 \%)$ were able to collect high call rate samples for both types of swabs. In conclusion, sponge-tipped swabs were acceptable to patients, and provided good quality DNA of sufficient yield for qPCR based pharmacogenetic testing. 


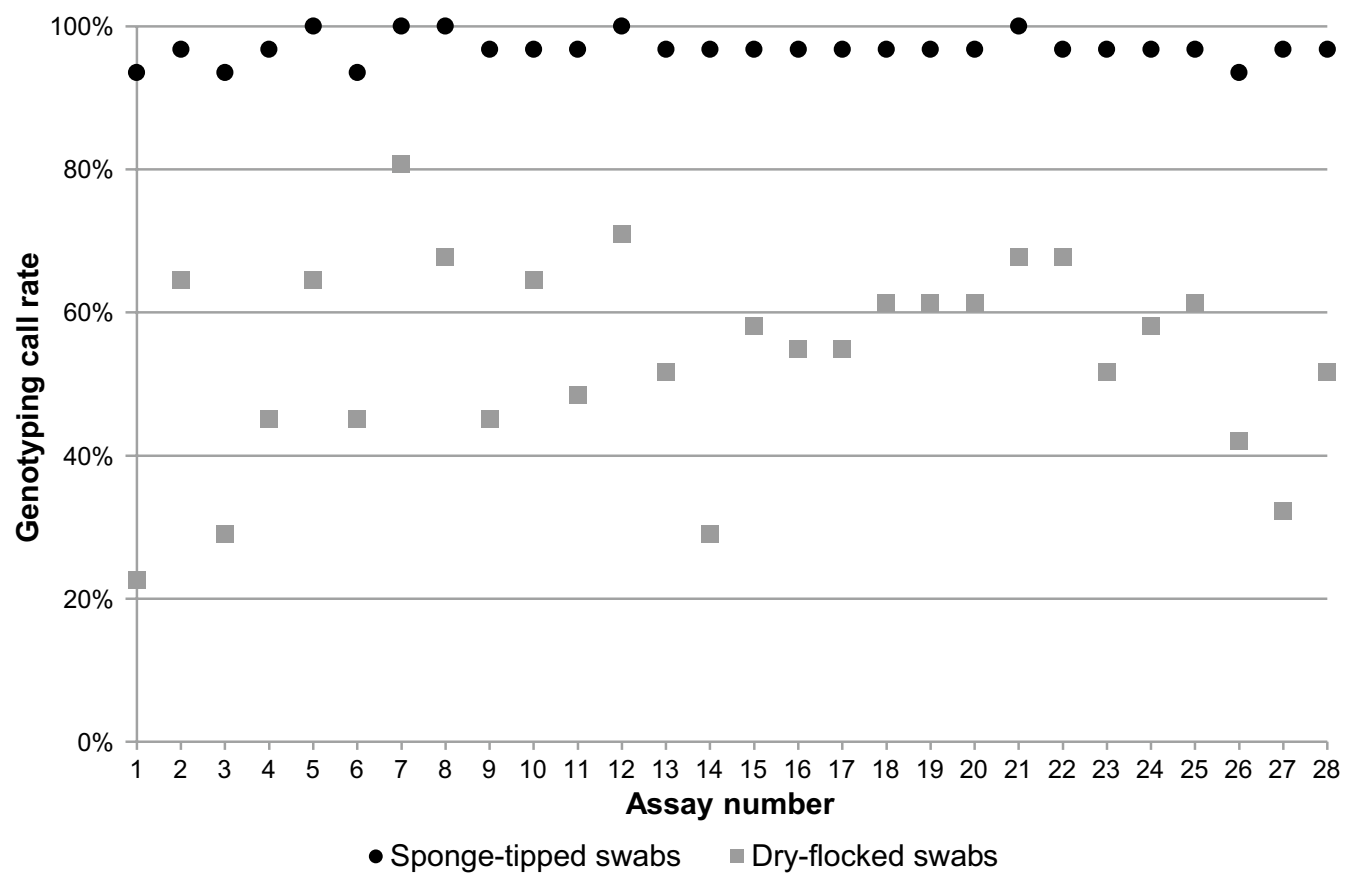

Fig. 2 Mean genotyping call rate across a 28 SNP pharmacogenetic panel on the OpenArray platform

\section{Limitations}

The study provides support for an easy to collect swab for pharmacogenetic testing. Limitations to the study include small sample size and possible differences in sample collection technique between individuals. Moreover, only two types of swabs from those available on the market were tested, and the study did not include comparisons with other types of collection methods such as blood or saliva from the same individual.

\section{Additional files}

Additional file 1. Summary of studies evaluating collection types for various genetic applications.

Additional file 2. List of SNPs on the OpenArray panel.

Additional file 3. Copy number calls for DNA samples genotyped on a CYP2D6 CNVTaqMan Assay.

\section{Abbreviations}

CPIC: Clinical Pharmacogenetics Implementation Consortium; DPWG: Dutch Pharmacogenetics Working Group; SNP: single nucleotide polymorphism; CYP2D6: cytochrome P450 family 2 subfamily D member 6; $\mathrm{OD}_{\mathrm{A260/280}}$ : optical density A260/280; CNV: copy number variation; APCR: quantitative polymerase chain reaction; NIGMS: National Institute of General Medical Sciences; NTC: no template control.

\section{Authors' contributions}

Study design (HKE, DD, MD2, RF); sample collection (AP, PS); conducting of study and data collection (HKE, JSA, MA); analysis and interpretation of results (HKE, JSA, MD2, DD); literature search (HKE, JSA); manuscript writing (all authors); critical review of the manuscript (DD, MD1, MD2, MA, ASG, AP,
PS) manuscript revision (HKE, JSA). All authors read and approved the final manuscript

\section{Author details}

${ }_{1}^{1}$ GenXys Health Care Systems Inc., Vancouver, BC, Canada. ${ }^{2}$ Department of Physical Therapy, University of British Columbia, Vancouver, BC, Canada. ${ }^{3}$ Shoppers Drug Mart Corporation, Vancouver, BC, Canada. ${ }^{4}$ Molecular You Inc., Vancouver, BC, Canada. ${ }^{5}$ Personalized Medicine Initiative, University of British Columbia, Vancouver, BC, Canada. ${ }^{6}$ Clinicare Pharmacists Inc, Vancouver, BC, Canada. ${ }^{7}$ Department of Family Practice, University of British Columbia, Vancouver, BC, Canada.

\section{Acknowledgements}

The authors gratefully thank Dr. Gideon Liknaitzky for assistance with the sample collection process and our study volunteers for their participation.

\section{Competing interests}

The authors declare that they have no competing interests.

\section{Availability of data and materials}

The data used and/or analysed during the current study are available from the corresponding author on reasonable request.

\section{Consent for publication}

Not applicable.

\section{Ethics approval and consent to participate}

Written informed consent for sample collection and genotyping was obtained from all participants. The study was approved by the University of British Columbia Research Ethics Board.

\section{Funding}

Support for this work was provided by the Canadian Institutes of Health Research REACH grant. The funding agency had no role in the writing of the article. 


\section{Publisher's Note}

Springer Nature remains neutral with regard to jurisdictional claims in published maps and institutional affiliations.

Received: 10 April 2018 Accepted: 4 June 2018

Published online: 14 June 2018

\section{References}

1. Wang L, McLeod HL, Weinshilboum RM. Genomics and drug response. N Engl J Med. 2011;364:1144-53.

2. Relling MV, Evans WE. Pharmacogenomics in the clinic. Nature. 2015;526:343-50.

3. Cardelli M, Marchegiani F, Corsonello A, Lattanzio F, Provinciali M. A review of pharmacogenetics of adverse drug reactions in elderly people. Drug Saf. 2012:35:3-20.

4. Dawes M, Aloise MN, Ang JS, Cullis P, Dawes D, Fraser R, Liknaitzky G, Paterson A, Stanley P, Suarez-Gonzalez A, Katzov-Eckert H. Introducing pharmacogenetic testing with clinical decision support into primary care: a feasibility study. CMAJ Open. 2016:4:E528-34.

5. Relling MV, Klein TE. CPIC: clinical pharmacogenetics implementation consortium of the pharmacogenomics research network. Clin Pharmacol Ther. 2011:89:464-7.

6. Swen JJ, Nijenhuis M, de Boer A, Grandia L, Maitland-van der Zee AH, Mulder H, Rongen $G$, van Schaik RHN, Schalekamp T, Touw DJ, et al. Pharmacogenetics: from bench to byte — an update of guidelines. Clin Pharmacol Ther. 2011;89:662-73.

7. Whirl-Carrillo M, McDonagh EM, Hebert JM, Gong L, Sangkuhl K, Thorn CF, Altman RB, Klein TE. Pharmacogenomics knowledge for personalized medicine. Clin Pharmacol Ther. 2012;92:414-7.

8. Rogers NL, Cole SA, Lan H-C, Crossa A, Demerath EW. New saliva DNA collection method compared to buccal cell collection techniques for epidemiological studies. Am J Human Biol. 2007;19:319-26.

9. Woo JG, Sun G, Haverbusch M, Indugula S, Martin LJ, Broderick JP, Deka R, Woo D. Quality assessment of buccal versus blood genomic DNA using the Affymetrix 500K GeneChip. BMC Genet. 2007;8:79.

10. Ng DPK, Koh D, Choo S, Chia K-S. Saliva as a viable alternative source of human genomic DNA in genetic epidemiology. Clin Chim Acta. 2006;367:81-5.
11. Calderwood L, Rose N, Ring S, McArdle W. Collecting saliva samples for DNA extraction from children and parents: findings from a pilot study using lay interviewers in the UK. Survey Methods Insights Field. 2014. https://doi.org/10.13094/SMIF-2014-00002.

12. Pulford DJ, Mosteller M, Briley JD, Johansson KW, Nelsen AJ. Saliva sampling in global clinical studies: the impact of low sampling volume on performance of DNA in downstream genotyping experiments. BMC Med Genomics. 2013;6:20.

13. Abraham JE, Maranian MJ, Spiteri I, Russell R, Ingle S, Luccarini C, Earl HM, Pharoah PP, Dunning AM, Caldas C. Saliva samples are a viable alternative to blood samples as a source of DNA for high throughput genotyping. BMC Med Genomics. 2012:5:19.

14. Walker AH, Najarian D, White DL, Jaffe JF, Kanetsky PA, Rebbeck TR. Collection of genomic DNA by buccal swabs for polymerase chain reactionbased biomarker assays. Environ Health Perspect. 1999;107:517-20.

15. TVO Hansen, Simonsen MK, Nielsen FC, Hundrup YA. Collection of blood, saliva, and buccal cell samples in a pilot study on the danish nurse cohort: comparison of the response rate and quality of genomic DNA. Cancer Epidemiol Biomark Prev. 2007;16:2072.

16. Satia A, King IB, Abouta JS, Thornquist MD, Bigler J, Patterson RE, Kristal AR, Shattuck AL, Potter JD, White E. Buccal cell DNA yield, quality, and collection costs. Cancer Epidemiol Biomark Prev. 2002;11:1130.

17. Bruinsma FJ, Joo JE, Wong EM, Giles GG, Southey MC. The utility of DNA extracted from saliva for genome-wide molecular research platforms. BMC Res Notes. 2018;11:8.

18. Glasel JA. Validity of nucleic acid purities monitored by $260 \mathrm{~nm} / 280 \mathrm{~nm}$ absorbance ratios. Biotechniques. 1995;18:62-3.

19. Wilfinger WW, Mackey K, Chomczynski P. Effect of pH and ionic strength on the spectrophotometric assessment of nucleic acid purity. Biotechniques. 1997;22(474-476):478-81.

20. Laurie CC, Doheny KF, Mirel DB, Pugh EW, Bierut $L$, Bhangale T, Boehm F, Caporaso NE, Cornelis MC, Edenberg HJ, et al. Quality control and quality assurance in genotypic data for genome-wide association studies. Genet Epidemiol. 2010;34:591-602.

21. Anderson CA. Chapter 7-Data quality control. In: Morris A, editor. Analysis of complex disease association studies. San Diego: Academic Press; 2011. p. 95-108.

22. CopyCaller ${ }^{\circledR}$ Software v2.0 User's Manual. Life Technologies; 2011.
Ready to submit your research? Choose BMC and benefit from:

- fast, convenient online submission

- thorough peer review by experienced researchers in your field

- rapid publication on acceptance

- support for research data, including large and complex data types

- gold Open Access which fosters wider collaboration and increased citations

- maximum visibility for your research: over $100 \mathrm{M}$ website views per year

At BMC, research is always in progress.

Learn more biomedcentral.com/submissions 